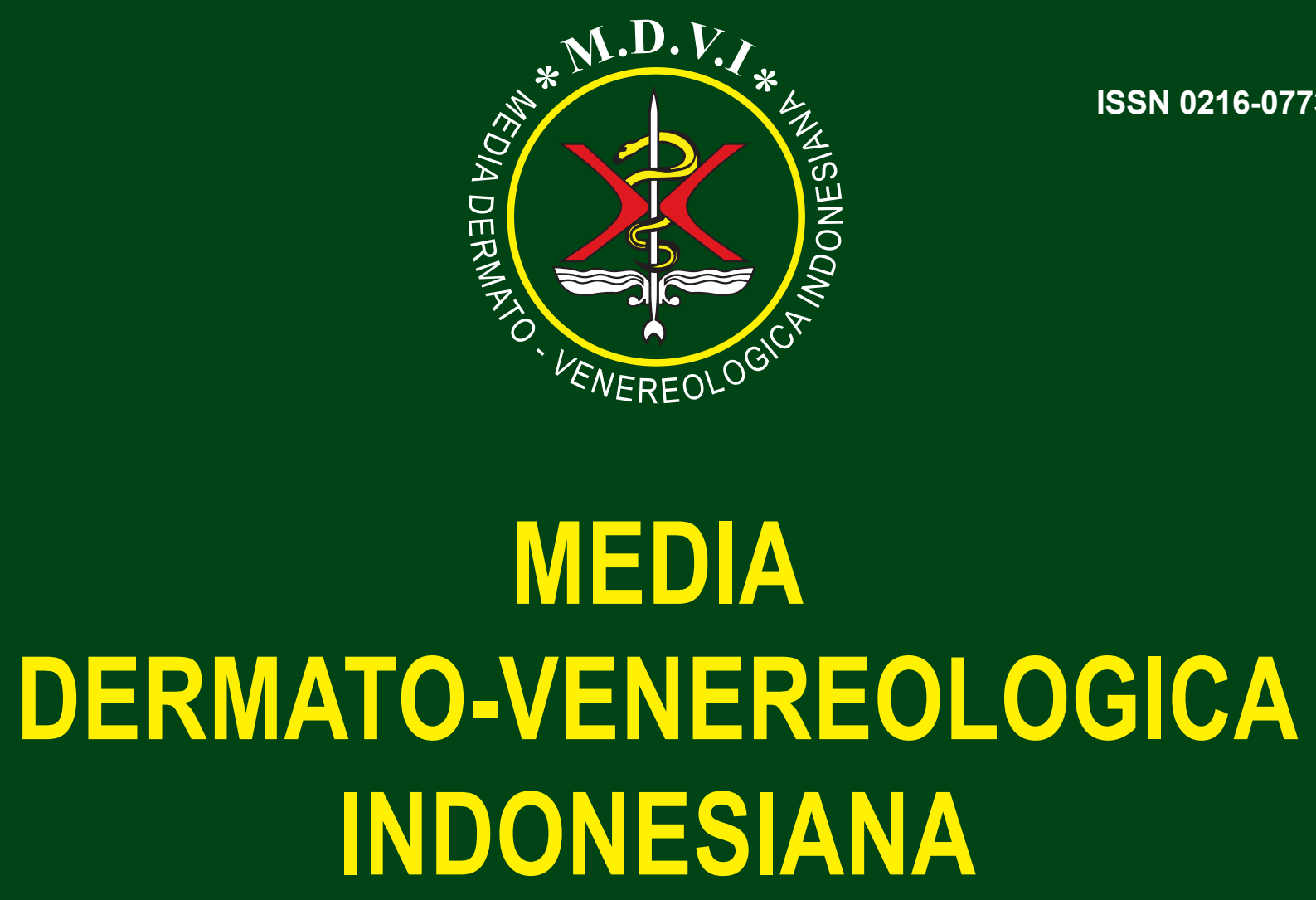

Editorial : Trias epidemiologis : Pendekatan memahami orkestra sistem imunologi kulit

Uji klinis sampo formulasi khusus pada pasien ketombe dan dermatitis seboroik ringan pada skalp

Tingkat pengetahuan dan sikap pekerja binatu terhadap dermatitis kontak

Korelasi antara kadar superoksida dismutase dengan malondialdehid pada jaringan keratosis seboroik

Psoriasis vulgaris berat diterapi mikofenolat mofetil: tantangan dalam pengobatan

Terapi dapson pada pemfigoid bulosa

Modern wound dressing pada ulkus trofik pasien kusta tipe lepromatosa

Peningkatan enzim transaminase pada kusta

Korelasi gambaran histopatologi, teknik biopsi dan manifestasi klinis vaskulitis leukositoklastik kutan

Peran mikrobiom pada infeksi menular seksual

Melasma dalam sudut pandang genetik 


\title{
MELASMA \\ DALAM SUDUT PANDANG GENETIK
}

\author{
Betty Ekawati Suryaningsih \\ Bagian Ilmu Kesehatan Kulit dan Kelamin \\ FK Universitas Islam Indonesia, Yogyakarta
}

\begin{abstract}
ABSTRAK
Melasma merupakan kelainan hiperpigmentasi pada wajah dan terdistribusi secara simetris. Lebih banyak terjadi pada wanita usia reproduktif dan banyak terjadi pada seseorang dengan tipe kulit III-V. Melasma sering memberikan dampak negatif pada kualitas hidup pasien dalam hubungan sosial. Kelainan ini sangat sulit diobati dan memerlukan biaya yang cukup mahal, namun sering tidak memuaskan baik bagi pasien maupun dokter yang menanganinya. Patogenesis melasma bersifat multifaktor dan belum dapat dijelaskan sepenuhnya. Faktor genetik, hormon, dan pajanan ultra-violet (UV) merupakan faktor risiko melasma. Dari semua faktor tersebut diduga faktor genetik dan pajanan matahari berperan utama dalam patogenesis melasma. Selain itu riwayat melasma dalam keluarga juga merupakan faktor risiko. Beberapa penelitian terbaru menemukan beberapa ekspresi gen dan melibatkan beberapa jalur yang berperan dalam patogenesis melasma. Gen melanocortin-1 receptor (MC1R) merupakan salah satu gen yang diduga berperan secara genetik pada melasma.
\end{abstract}

Key words: Melasma, genetik, hormonal, pajanan UV dan MC1-R

\section{MELASMA \\ IN A GENETIC PRESPECTIVE}

\begin{abstract}
Melasma is a hyperpigmentation disorder with symmetrical distribution mostly over the face and more commonly fpund among women of reproductive age and among individuals with skin types III-V. It often has a negative impact on patients' quality of life in social relations,. This disorder is very difficult to treat and the cost for the treatment is very expensive to pay but no satisfactory result for patient and dermatologist. The pathogenesis of melasma is unclear and multi-factorial; genetic factors, hormone and sun exposure are risk factors to melisma. The genetic factor and sun exposure are played major role in the pathogenesis of melasma. Family history is also a risk factor for the melasma. Several recent studies have found several gene expressions and involve several pathways that play a role in the mechanism of melasma. The melanocortin-1 receptor (MC1-R) gene is one gene that is thought to have a genetic role to cause melasma.
\end{abstract}

Keywords: Melasma, genetic, hormonal, UV exposure and MC1-R

\section{Korespondensi:}

Jln. Kaliurang km 14,5 Sleman, Yogyakarta Telpon: 0274-898444, 0811256307

Email: beshelios@gmail.com betty.e.s@uii.ac.id 


\section{PENDAHULUAN}

Melasma merupakan kelainan dengan etiopatogenesis multifaktor diduga akibat interaksi antara faktor genetik, lingkungan, dan juga fototipe kulit. Hingga saat ini patogenesisnya belum dapat dijelaskan sepenuhnya. ${ }^{1-3}$ Belum banyak pula penelitian tentang karakter pewarisan genetik pada melasma yang berhubungan dengan warna kulit. ${ }^{4-7}$ Warna kulit manusia ditentukan oleh jenis pigmen eumelanin dan pheomelanin yang diregulasi oleh gen melanocortin-1 receptor $(M C 1 R)$ dan agouti signaling protein (ASIP), serta dipengaruhi oleh letak geografis tempat seseorang tersebut berasal.--9 Kedua gen tersebut bersifat polimorfisme yang menyebabkan perubahan fungsi protein dalam tubuh sehingga dapat menimbulkan berbagai kelainan pigmentasi yang diwariskan. ${ }^{10}$ Dalam makalah ini akan dibahas faktor genetik, yaitu gen $M C 1 R$ yang diduga berperan dalam patognesis melasma.

\section{Sistem Pigmentasi pada Kulit Manusia}

Warna kulit, rambut, dan mata yang terlihat pada setiap orang disebabkan oleh pigmen melanin di jaringan tersebut. Melanin sendiri diproduksi oleh sel spesifik, yaitu melanosit, yang berperan penting tidak hanya pada tipe melanin, tetapi juga pada distribusinya, dan akan berdampak pada warna jaringan yang menjadi tujuan akhir migrasi. Selain memberikan warna pada seseorang, melanin juga berfungsi sebagai fotoproteksi. ${ }^{11,12-14}$ Melanin merupakan kompleks pigmen polimerik dan mempunyai dua bentuk dasar pada kulit manusia, yaitu eumelanin yang berwarna cokelat kehitaman dan feomelanin untuk pigmen yang berwarna kuning kemerahan. Kedua tipe melanin ini berbeda, baik susunan biokimia dan sifat fotoprotektifnya maupun rumus bangunnya, mulai dari melanosom tempat kedua melanin tersebut diproduksi atau dihasilkan. ${ }^{13-15}$ Pigmentasi pada manusia bersifat genetik melibatkan gen $M C 1 R$ dan sangat kompeks dalam proses melanogenesis. ${ }^{13,14,16}$

\section{Etiopatogenesis Melasma}

Etiopatogenesis melasma bersifat multifaktorial dan belum dapat dijelaskan sepenuhnya. Genetik, hormon, lingkungan dan pajanan ultra violet (UV) merupakan faktor risiko melasma. ${ }^{5,7}$ Beberapa penelitian terbaru menemukan beberapa ekspresi gen dan melibatkan beberapa jalur yang berperan dalam melasma. Dengan demikian, diduga etiopatogenesis, melibatkan respons inflamasi, stres oksidatif, dan metabolisme lipid. Hasil penelitian ini semakin menguatkan jika melanosit hanya merupakan sebagian dari kompleks komunikasi antar sel yang terlibat dalam patogenesis melasma, karena mekanisme tersebut juga melibatkan unit epidermis melanin. ${ }^{22,23}$ Beberapa faktor yang memengaruhi perkembangan melasma dijelaskan sebagai berikut di bawah ini.

\section{Faktor Genetik}

Gen Melanocortin 1 Receptor (MCIR) berperan pada pigmentasi kulit. Variasi warna kulit pada manusia ditentukan oleh produksi melanin. Melanin merupakan campuran bipolimer dengan kandungan psikokimiawi yang berbeda. Campuran bipolimer tersebut berasal dari asam amino tirosinase. Ada dua jenis melanin, yaitu eumelanin dan feomelanin. Eumelanin mengabsorbsi sinar matahari dan menangkap radikal bebas lebih banyak dibandingkan dengan feomelanin. Kedua melanin tersebut diregulasi oleh gen MC1R, yang merupakan mediator sinyal transduksi alpha melanocyte stimulating hormone ( $\alpha-\mathrm{MSH})$ yang selanjutnya mengaktivasi adenil siklase intraseluler dan adenosine monophosphate cyclic (cAMP), yang merupakan pencetus untuk mengaktivasi tirosinase dalam jalur sintesis melanin. ${ }^{10,17,19,29}$ Selain sebagai regulator sistem melanin $M C l R$ juga sebagai pengontrol point responds melanosit terhadap pajanan UV dan juga merupakan faktor risiko penting untuk kanker kulit, terutama melanoma. ${ }^{13,29}$

Polimorfisme gen $M C 1 R$ yang banyak berhubungan dengan warna kulit adalah polimorfisme Val92Met dan Arg163Gln. Perubahan asam amino valin (Val) menjadi metionin (Met) atau asam amino arginin (Arg) menjadi glutamin (Gln) akan menyebabkan menurunnya fungsi gen $M C 1 R$ dalam berikatan dengan MSH ${ }^{10,19}$ Menurunnya fungsi gen $M C 1 R$ untuk mengaktivasi cAMP berhubungan dengan kejadian freckles pada kulit yang terang atau putih, dan rambut yang berwarna merah pada populasi keturunan Eropa yang mayoritas penduduknya memiliki kulit tipe $\mathrm{I}^{20} \mathrm{Hal}$ tersebut terjadi karena tipe kulit I memproduksi pigmen tambahan atau melanosom yang masih berada pada fase I atau II, sementara pada populasi Asia dengan tipe kulit III - V produksi pigmennya maksimal, sehingga kelainan hiperpigmentasi yang banyak dijumpai berupa melasma., ${ }^{3,11}$ Gen $M C 1 R$ terdapat pada banyak sel melanosit, termasuk di keratinosit, fibroblas, sel endotel, dan antigen presenting cells. Pigmentasi pada manusia bersifat genetik dan sangat kompleks dalam proses pembentukannya. Gen $M C 1 R$ berperan dalam fisiologi warna kulit dan rambut. $12,14,29,30$

Gen MC1R berperan sentral dalam melindungi melanin dari pajanan UV, melalui stimulasi oleh $\alpha-\mathrm{MSH}$, adrenocorticotropic hormone (ACTH), sitokin dan growth factor antara lain IL-1, endotelin-1 dan basic fibroblast growth factor (bFGF). Jika $M C-1 R$ berikatan dengan ligan, akan meningkatkan aktivasi c-AMP intraseluler, dendrit, dan menstimulasi ekspresi serta mengaktivasi tirosinase dan protein melanogenik lainnya, rangkaian proses tersebut akan meningkatkan produksi pigmen eumelanin di dalam proses biosinteis melanin. Sebaliknya, jika gen $M C 1 R$ mengalami disfungsi dan gagal berikatan dengan ligan untuk menginduksi c-AMP, maka akan lebih banyak produksi pigmen feomelanin. ${ }^{16,18}$ Aktivasi c-AMP selanjutnya akan mengaktivasi protein kinase $A$ (PKA) dan menempatkan gugus fosfat pada protein lainnya. Salah satu gugus fosfat tersebut akan mengalami fosforilasi oleh PKA menjadi $c-A M P$ 
response-element binding protein (CREB) yang berfungsi sebagai faktor transkripsi, regulasi dan ekspresi gen lainnya, termasuk micropthalmia-associated transcription factor (MITF). ${ }^{13,16}$

Faktor predisposisi familial pada melasma merupakan hal yang penting secara genetik, meskipun polanya nonMendelian. Diduga faktor genetik berperan dalam terjadinya melasma. ${ }^{3,22}$ Tipe kulit III-V merupakan faktor predisposisi genetik terjadinya melasma dibandingkan dengan orang dengan tipe kulit putih. Pajanan sinar matahari pada tipe kulit III-V diduga meningkatkan aktivitas unit melanin epidermis yang berperan dalam patogenesis melasma. Namun demikian, belum banyak penelitian tentang karakter pewarisan multigenetik pada melasma. ${ }^{3,7,22}$ Pada penelitian melasma terhadap 324 perempuan di sembilan negara (Amerika, Prancis, Jerman, Belanda, Mexico, Italia, Singapore, Korea Selatan, dan Hongkong) pada tahun 2009, didapatkan data sebanyak $48 \%$ pasien melasma memiliki riwayat penyakit serupa di keluarga dan $97 \%$ kasus di antaranya terjadi pada generasi pertama, sedangkan 3\% terjadi pada generasi kedua dalam anggota keluarga. ${ }^{24}$ Penelitian lainnya di Tunisia menunjukkan interaksi antara genetik dengan lingkungan yang sangat bervariatif dan pada sekitar $10 \%-70 \%$ populasi terdapat riwayat keluarga dengan melasma. ${ }^{4}$

Riwayat keluarga dan meningkatnya jumlah pasien melasma pada ras tertentu menunjukkan peran genetik pada kelainan tersebut. Predisposisi genetik paling sering terjadi pada wanita. Pemeriksaan analisis microarray pada lesi hiperpigmentasi pasien melasma menunjukkan downregulation gen H19 yang berdampak menstimulasi melanogenesis pada pasien melasma. Pemeriksaan ini merupakan suatu titik awal yang baik untuk penelitian faktor genetik sebagai salah satu faktor terjadinya melasma. ${ }^{4,25}$ Pada dekade terakhir ini di antara beberapa peneliti menduga bahwa melasma merupakan kelainan yang poligenik dan dipengaruhi oleh epigenetik melanogenesis. $^{22,25}$

Faktor genetik merupakan salah satu faktor risiko terjadinya melasma, namun belum banyak penelitian tentang hal tersebut. Penelitian retrospektif yang dilakukan oleh Suryaningsih BE pada tahun 2018, ${ }^{30}$ tentang hubungan polimorfisme gen MC1R dengan melasma, membuktikan hubungan antara kejadian melasma dengan faktor genetik. Polimorfisme gen MC1R, yaitu genotip heterozigot Val/Met merupakan faktor risiko melasma pada populasi wanita suku Jawa di Yogyakarta dengan nilai (OR: 2,53; 95\%CI 1,21-5,29). Selain faktor riwayat keluarga dengan kelainan melasma, pajanan matahari juga merupakan faktor risiko melasma. Dari hasil penelitian tersebut ditarik kesimpulan bahwa melasma terjadi karena adanya interaksi yang kompleks antara beberapa faktor dan faktor genetik cukup adekuat untuk terjadinya melasma paada studi ini. ${ }^{30}$

\section{Faktor Pajanan Matahari}

Pajanan UV merupakan pencetus terbesar melasma. Radiasi UV akan meningkatkan proliferasi melanosit dan melanogenesis. Pajanan matahari menyebabkan hiperpigmentasi akibat meningkatnya pigmen melanin yang disintesis di dalam melanosom; dengan bantuan enzim spesifik tirosinase akan terjadi melanogenesis secara lengkap melalui sinyal MSH, dan aktivasi beberapa reseptor dan enzim melanogenik. Hiperpigmentasi yang diinduksi sinar UV akan segera sembuh spontan, sementara pada melasma hal tersebut tidak terjadi. ${ }^{21,26,27}$ Jalur utama dan penting di dalam melanogenesis, cAMP akan mengaktifkan PKA, selanjutnya akan menstimulasi CREB yang merupakan faktor transkripsi dan meningkatkan ekspresi regulasi MITF. Dengan ikatan MITF dan tirosinase akan meningkatkan sintesis melanin. ${ }^{11,26}$

\section{Faktor Hormon}

Peranan hormon belum sepenuhnya dapat dijelaskan dalam kejadian melasma. Namun diyakini hormon estrogen dan progesteron terlibat di dalam patogenesis melasma. Melanosit pada kulit yang sehat memiliki nukleus dan reseptor estrogen sitosolik. Di lesi melasma, jumlah reseptor tersebut meningkat. Beberapa hormon berpengaruh pada melanosit, yaitu: melanocyte stimulating hormone (MSH), adrenocorticotropic hormone (ACTH), lueteinizing hormone (LH), follicle stimulating hormone (FSH), semua hormon tersebut akan meningkatkan ukuran melanosit dan produksi tirosinase. ${ }^{28}$ Beberapa penelitian klinik membuktikan bahwa hormon estrogen dapat memicu melasma pada wanita. Pada 90\% kasus melasma didapatkan sekitar 50\%-70\% adalah perempuan hamil dan 10\%-20\% adalah perempuan pengonsumi kontrasepsi oral. Melasma mulai timbul antara satu sampai tiga tahun setelah seseorang mengonsumsi kotrasepsi hormonal. 21,26 Penelitian yang dilakukan oleh Achar dan Rathi di India dari 250 subjek wanita menunjukkan bahwa pasien melasma yang hamil sebanyak 56 orang $(22,4 \%)$ dan pengguna kontrasepsi oral sebanyak 46 orang $(18,4 \%)$. Sementara itu, penelitian potong lintang di Iran menunjukkan bahwa pasien melasma didapatkan pada wanita hamil sebanyak 14,5\% dan pada perempuan yang menggunakan kontrasepsi oral atau pil pengatur kehamilan sebanyak $11,3 \%$. Semua penelitian tersebut menunjukkan korelasi antara hormonal dan melasma, namun bagaimana mekanisme tersebut terjadi belum dapat dijelaskan. ${ }^{26,27}$

\section{Faktor Parakrin}

Interaksi antarsel berperan penting sebagai homeostasis jaringan. Komunikasi antara melanosit dan keratinosit pada mekanisme melanogenesis. Pajanan matahari dalam mekanisme terjadinya melasma atau interaksi antara melanosit dengan fibroblas dermais baik dalam kondisi fisiologis maupun patologis. Mekanisme interaksi antar sel yang tampak pada 
warna kulit yang berbeda pada setiap area tubuh (topografi), disebabkan karena peranan protein Dickkopf 1 (DKK1) yang disekresi oleh fibroblast. DKKI akan menginhibisi jalur sinyal intra-sel ligan wingless-related integration site (Wnt) melalui jalur amplifikasi yang mengaktivasi $\beta$-catenin (jalur kanonikal) dalam sinyal pembentukan melanin atau menginhibisi fungsi dan proliferasi melanosit. Protein DKK1 meningkatkan pertumbuhan keratinosit, namun menurunkan pelepasan melanin oleh keratinosit. Melanogesis dapat terjadi karena pajanan UV, yang menginduksi sekresi stem cell factor (SCF). Peningkatan ekpresi SCF di dermis dibuktikan dengan pewarnaan imunohistokimia pada lesi kulit hiperpigpmentasi pasien melasma. ${ }^{26}$

Mekanisme terjadinya melanogenesis lainnya adalah melalui protein wingless-related integration site inhibitor factor-1 (WIF-1), penurunan ekspresi protein WIF-1 merupakan salah satu mekanisme yang dapat menstimulasi terjadinya melasma. Penurunan WIF-1 akan menghambat jalur sinyal intra-sel pada $\beta$-catenin (kanonikal) atau melalui berbagai respon biologi hasil dari jalur sinyal ligan Wnt (non kanonikal) di fibroblast dan keratinosit yang berperan di dalam proses melanogenesis dan transfer melanosom. Namun demikian, hingga saat ini data tentang peran parakrin dalam menimbulkan melasma masih berada dalam tahap permulaan. ${ }^{11,26}$

\section{Faktor Lain yang Terlibat}

Faktor lain yang diduga juga terlibat di dalam mekanisme terjadinya melasma adalah kelainan pembuluh darah dermis dan $\mathrm{pH}$ pada regulasi melanosom serta transport ion. Pemeriksaan dengan mikroskopi pada lesi melasma menunjukkan peningkatan jumlah dan ukuran pembuluh darah disertai dengan ekspresi vascular endothelial growth factor (VEGF). Kondisi ini mendukung peran vaskular pada patogenesis melasma. Peran $\mathrm{pH}$ dijelaskan sebagai berikut. Tirosinase akan menjadi tidak aktif dalam situasi lingkungan $\mathrm{pH}$ asam sehingga akan menganggu tahapan pembentukan melanosom terutama dalam produksi eumelanin. Pada ras kaukasoid melanosit berada dalam lingkungan $\mathrm{pH}$ asam sehingga mensupresi produksi melanin. Sebaliknya, pada orang dengan kulit yang berwarna lebih gelap menunjukkan $\mathrm{pH}$ netral. Namun bagaimana peranan $\mathrm{pH}$ pada melanosom dalam mekanisme melasma belum diketahui secara jelas. ${ }^{11,26,30}$ Selain faktor tersebut di atas, faktor lain yang dapat menyebabkan melasma adalah obat dan kosmetik, namun hingga saat ini mekanisme tersebut belum dapat dijelaskan. ${ }^{4}$ Gambar patogenesis melasma diringkas dalam gambar 1 di bawah ini.

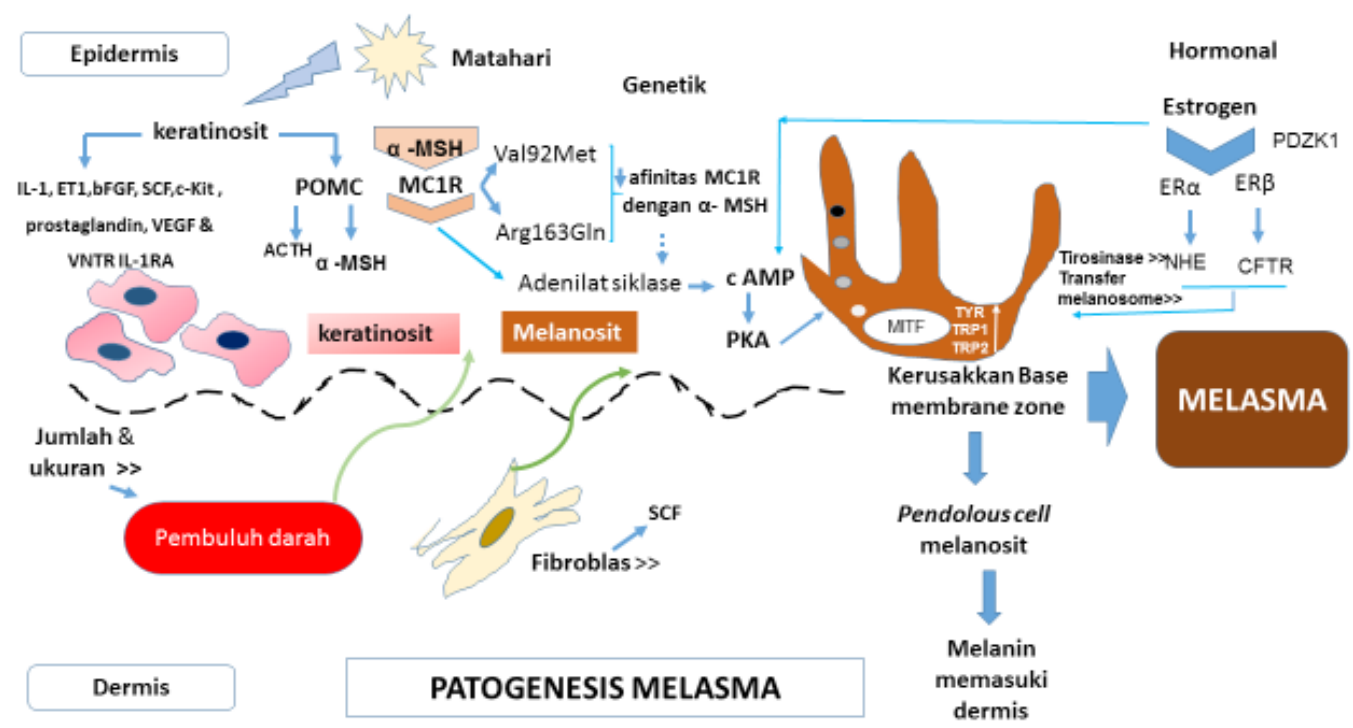

Gambar 1. Patogenesis melasma (sumber Suryaningsih BE,2018) 30 $^{30}$

Matahari, genetik dan hormonal memicu meningkatnya ekspresi seperti nerve growth factor (NGF), endothelin (ET1), stem cell factor (SCF), basic fibroblast growth factor (bFGF) dan proopiomelanocortin (POMC) yang berperan dalam melanogenesis. Polimorfisme Va192Met \& Arg163Gln menurunkan afinitas $M C 1 R$ dgn MSH namun melanogesis tetap berjalan melalui level cAMP sebagai jalur sinyal transduksi mayor. Hormon estrogen melalui ikatan dengan estrogen reseptor akan meningkatkan cAMP atau melalui interaksi dengan protein yang lain sehingga meningkatkan tirosinase dan transfer melanosom. Di dermis akan terjadi peningkatan dan ukuran pembuluh arah, selain itu juga didapatkan fibroblast yang berlebih 


\section{SIMPULAN}

Etiopatogenesis melasma bersifat multifaktor dan belum dapat dijelaskan sepenuhnya. Faktor genetik, hormon, dan pajanan UV merupakan faktor risiko melasma. Salah satu gen yang berperan dalam patogenesis melasma adalah gen $M C 1 R$, yaitu gen yang meregulasi sistem pigmen di kulit dan bertanggung jawab dalam rasio eumelanin dan feomelanin. Polimorfisme gen MC1R menyebabkan gangguan fungsi gen tersebut, sehingga merupakan salah satu faktor risiko melasma. Riwayat melasma dalam keluarga juga berperan cukup besar untuk terjadi melasma pada keturunannya. Faktor genetik yaitu MC1R merupakan faktor risiko yang adekuat untuk terjadinya melasma.

\section{DAFTAR PUSTAKA}

1. Brianezi G, Handel AC, Schmitt JV, Miot LDB, Miot HA Changes in nuclear morphology and chromatin texture of basal keratinocytes in melasma. JEADV.2015;29:809-12.

2. Ritter CG, Fiss DVC, Borges da Costa JAT, de Carvalho RR, Bauermann G, Cestari TF. Extra-facial melasma: clinical, histopathological, and immunohistochemical case-control study. JEADV. 2013; 27:1088-94.

3. Handel AC, Miot LDB, Miot HA. Melasma: a clinical and epidemiological review. An Bras Dermatol. 2014;89:771-82.

4. Guinot C, Cheffai S, Latreille J, Dhaoui M, Youssef S., Jaber K, Nageotte O, Doss N. Aggravating factors for melasma: a prospective study in 197 Tunisian patients. JEADV. 2010;24:1609.

5. Sonthalia S, Sarkar R. Etiopathogenesis of melasma. Pigment Int.2015;2:21-7.

6. Sarkar R, Arora P, Garg V.K, Sonthalia S, Gokhale N. Melasma update. Indian Dermatol. Online J.2014; 5: 426-35.

7. Tzouveka E. Epidemiology and risk factors of melasma...Journal of Pigmentary Disorder2014;1:1-3.

8. Videira IF dos S, Moura DFL, Magina S. Mechanisms regulating melanogenesis*. An Bras Dermatol. 2013;88:76-83.

9. Arora P, Garg V, Sonthalia S, Gokhale N, Sarkar R. Melasma update. Indian Dermatol. Online J 2014 ; 5: 426-9.

10. Carroll L, Voisey J, Van Daal A. Gene polymorphisms and their effects in the melanocortin system. Peptides 2005;26:1871-85.

11. Cichorek M, Wachulska M, Stasiewicz A, Tymińska A. Skin melanocytes: biology and development. Adv Dermatol Allergol. 2013;1:30-41.

12. Bolognia Jean L dan Orlow Seth JMelanocyte Biology. chapter 65.Dermatology. Edisi ke-3. Philadelphia: WB Saunders; 2012.h.1011-21 .

13. Tsatmali M, Ancans J, Thody AJ. Melanocyte function and its control by melanocortin peptides. J. Histochem \& Cytochem. 2002;50:125-33.
14. Schaffer Julie V dan Bolognia Jean L. The Biology of The Melanocyte: Cancer of the Skin. Edisi ke-2. New York: Saunders; 2011.h.23-38 .

15. Dessinioti C, Antoniou C, Katsambas A, Stratigos AJ. Melanocortin 1 Receptor Variants: Functional Role and Pigmentary Associations.Photochemestry and Photobiology.2011;87:978-87.

16. Switonski M, Mankowska M, Salamon S. Family of melanocortin receptor (MCR) genes inmammals--mutations, polymorphisms and phenotypic effects. J Appl Genet. 2013;54:461-72.

17. García-Borrón JC, Sánchez-Laorden BL, Jiménez-Cervantes C. Melanocortin-1 receptor structure and functional regulation. Pigment Cell Res.2005; 18: 393-410.

18. Schallreuter KU. Advances in Melanocyte Basic Science Research. Dermatol Clin. 2007;25:283-91.

19. Abdel-Malek ZA, Knittel J, Kadekaro AL, Swope VB, Starner R. The Melanocortin 1 Receptor and the UV Response of Human Melanocytes - A Shift in Paradigma. Photochemestry Photobiology. 2008;84:501-8.

20. Baxter Laura L dan Pavan William J. The etiology and molecular genetics of human pigmentation disorder. Wiley Interdisciplenary Reviews Developmental Biology. 2013;2(3): 379-92.

21. Damevska Katerina. New aspect of melasma. Serbian Journal of Dermatology and Venereology.2014;6(1): 5-18.

22. Guarneri F. Etiopathogenesis of Melasma. Pigment. Disord. 2014;(S)1:1-5.

23. Kang WH, Yoon KH, Lee E.-S, Kim J, Lee KB, Yim H, Sohn $\mathrm{S}$, Im S. Melasma: histopathological characteristics in 56 Korean patients. Br J Dermatol.2002;146:228-37.

24. Ortonne J, Arellano I, Berneburg M, Cestari T, Chan H, Grimes P, Hexsel D, ImS, Lim J, Lui H, Pandya A, Picardo M, Rendon M, Taylor S, Van Der Veen J, Westerhof W. A global survey of the role of ultraviolet radiation and hormonal influences in the development of melasma. JEADV. 2009; 23:1254-62

25. Chatterjee M, Vasudevan B. Recent advances in melasma. Pigment Int.2014;1:70-80

26. Lee AY.An updated review of melasma pathogenesis. Dermatol. Sinica. 2014; 32:233-9.

27. Rathi S, Achar, A. Melasma: A clinico-epidemiological study of 312 cases. Indian J Dermatol. 2011; 56:380-2

28. Kumre K, Varma K, Sharma H, Singh U. Study of hormonal profile in female melasma patient in a tertiary care hospital. J Evol Med Dent Sci. 2016;5:1663-6.

29. Suryaningsih BE, Sobono H. Biologi Melanosit. Majalah Dermato-Veneorologi Indonesia 2016:43(2);78-82.

30. Suryaningsih BE, Polimorfisme Gen Reseptor Melanokortin 1 (MC1R) dan Gen Antagonis Interleukin 1 (IL-1RA) Pada Melasma, Studi Pada Populasi Wanita Suku Jawa di Yogyakarta [Disertasi]. Yogyakarta: Universitas Gadjah Mada; 2018. 